Emir. J. Agric. Sci. 1995. 7: 87.99

\title{
Performance of Straightbred Friesian and Charolais X Friesian Crossbred Males Slaughtered at Three Different Ages
}

\author{
A.A. Nigm ${ }^{1}$, G.A. Alhadrami ${ }^{1}$, A.M. Kholif ${ }^{2}$ and O.M. \\ Abdulla ${ }^{1}$ \\ 1 Department of Animal Production, U.A.E. University. \\ P.O. Box 17555, Al-Ain, United Arab Emirates. \\ 2 National Research Center, Dokki, Giza, Egypt.
}

\section{ABSTRACT}

Eighteen 4-month old male calves; 9 straightbred Friesian (FxF) and 9 Charolais $x$ Friesian $(\mathrm{CxF})$ were used in fattening trial. Six were slaughtered at 4 months of age. The rest were fattened and slaughtered at 8 and 12 months of age. Concentrate and Rhodesgrass hay were offered ad libitum. Average daily gain (ADG), feed conversion ratio (FCR), slaughter weight (SW), hot carcass weight (HCW) and dressing percentage (DP) were calculated. Ribs (9th, 10th and 11th) were dissected into lean, fat and bone. Also, the Longissimus dorsi area (LDA) and fat thickness (FT) were measured over the 9th. Samples of Longissimus dorsi muscle were used for chemical analysis of meat.

Charolais crossed $(\mathrm{C} \times \mathrm{F})$ had higher $\mathrm{ADG}(\mathrm{P}<.01)$, and better FCR $(\mathrm{P}<.01)$ during the period from 4-8 months, resulting in heavier SW $(\mathrm{P}<.05)$ at 8 months, higher HCW, DP and percentage lean with less percentages of fat and bone in the rib cut, but differences were nonsignificant. Higher LDA $(\mathrm{P}<.05)$ in $\mathrm{C} \times \mathrm{F}$ indicating greater cutability.

Delay of slaughter to 8 or 12 months increased SW, LDA, HCW $(\mathrm{P}<.0001)$, improved DP $(\mathrm{P}<.05)$ and reduced bone \% in ribs cut $(\mathrm{P}<.0001)$. This was accompanied by higher fat $\%$ and an increase of FT. Results indicated that the use of Charolais and slaughter delay would improve efficiency of dairy beef production in the United Arab Emirates.

Key words: Straightbred, Crossbred, Friesian, Charolais, Slaughtered, U.A.E. 


\section{INTRODUCTION}

In the last two decades numerous dairy farms have been established in the United Arab Emirates. Replacement heifers are imported almost annually, but very few farms raise small proportion of their own replacements. Male and female progeny are sold for slaughter and with only $20 \%$ self sufficiency in red meat, efficient system of dairy beef production is needed.

Use of semen from beef bulls to inseminate dairy cows has been widely practiced in Europe. Beef sires improved significantly body weight, feed conversion efficiency and carcass composition of the crossbred progeny (Berg and Butterfield, 1976; Berg et al., 1978; Kempster et al., 1982 and Kempster et al., 1988). The adoption of a sire breed that meet individual producer requirements should be based on accurate information on the relative performance of breeds in different production systems. The use of semen from beef breeds to inseminate Friesian cows is increasingly practiced in the U.A.E.

As animals grow, the increase in weight gain and changes in carcass composition are used to determine the optimum age (S) at slaughter. The objectives of this study are to compare weight gain, feed efficiency and carcass traits of straightbred Friesian (F x F) with Charolais crosses $(\mathrm{C} \times \mathrm{F})$ and to study the effect of age at slaughter on performance of the two genotypes under U.A.E. conditions.

\section{MATERIALS AND METHODS}

This experiment was carried out at the Faculty of Agricultural Sciences Farm, United Arab Emirates University, for 8 months. Eighteen 4 months old male calves $(105.2 \pm 3.4 \mathrm{~kg}$ live weight) were bought from a local dairy farm and used in fattening trial. Nine were straightbred Friesian $(\mathrm{F} \times \mathrm{F})$, from dams of German origin with $75 \%$ Holstein blood, and the other nine were Charolais crosses ( $\mathrm{C} \mathrm{x}$ F) from Friesian dams with Charolais semen. Six calves (3 FxF \& 3 $\mathrm{CxF}$ ) were slaughtered at $4 \mathrm{mos}$. of age. The rest were fattened and slaughtered at 8 and 12 months of age.

Animals were housed in individual open shaded pens. Diet consisted of Rhodesgrass (Chloris gayana) hay and pelleted concentrates. Animals were fed ad libitum and had free access to water and trace mineralized salt blocks. Chemical composition of feed is 
shown in Table 1.

Table 1: Chemical composition of experimental feed ${ }^{1}$.

Concentrate Rhodesgrass

$\%$ of $\mathrm{DM}$

$\begin{array}{lll}\text { Crude protein } & 19.4 & 5.9\end{array}$

$\begin{array}{lll}\text { Ether extract } & 3.6 & 1.7\end{array}$

$\begin{array}{lll}\text { Crude fiber } & 6.1 & 28.5\end{array}$

$\begin{array}{lll}\text { Ash } & 6.9 & 9.5\end{array}$

${ }^{1}$ Each value is the mean of two observations.

All organs of slaughtered calves were weighed separately. The three rib $(9,10$ and 11) cuts were taken from the left side of each carcass. Fat thickness (FT) over the Longissimus dorsi of the 9th rib and Longissimus dorsi area (LDA) were measured. Rib (9, 10 and 11) cuts were dissected physically into lean, fat and bone. Chemical composition of meat from $L$. Dorsi muscles were analyzed according to AOAC (1984).

The following traits were recorded or calculated: slaughter weight (SW); average daily gain (ADG); dry matter intake (DMI); feed conversion ratio (FCR); hot carcass weight (HCW); empty body weight (EBW); and cold carcass weight (CCW).

Statistical analyses were performed using MSTAT (Michigan State Univ. 1985). Two statistical models were used: the first to analyse BW, ADG, DMI and FCR. Reads $Y_{i j}=U+g_{i}+e_{i j}$ where $\mathrm{Y}_{\mathrm{ij}}=$ an individual observation, $\mathrm{U}=$ overall mean, $\mathrm{g}_{\mathrm{i}}=$ an effect due to the $\mathrm{i}$ th genotype ( $\mathrm{F} \times \mathrm{F}$ or $\mathrm{C} \times \mathrm{F}$ ) and $\mathrm{e}_{\mathrm{ij}}=$ an error term. The second model was used to analyse carcass charcteristics and reads: 
$\mathrm{Y}_{\mathrm{ijk}}=\mathrm{U}+\mathrm{g}_{\mathrm{i}}+\mathrm{a}_{\mathrm{j}}+(\mathrm{ga})_{\mathrm{ij}}+\mathrm{e}_{\mathrm{ijk}}$ where $\mathrm{a}_{\mathrm{i}}=$ an effect due to age at slaughter, $\left(4,8\right.$ or 12 months) and $(\mathrm{ga})_{\mathrm{ij}}$ an effect due to the interaction between genotype and age. The other components are the same as defined in the first model.

\section{RESULTS AND DISCUSSION}

Means and mean squares of SW, ADG, DMI and FCR for straightbred Friesian $(\mathrm{F} \times \mathrm{F})$ and Charolais $\mathrm{x}$ Friesian $(\mathrm{C} \times \mathrm{F})$ are shown in Table 2. Charolais crosses had heavier SW at 8 and 12 months but differences were only significant $(\mathrm{P}<.05)$ at 8 mos. The higher SW of $\mathrm{C} \times \mathrm{F}$ at 8 mos. is attributed to higher $(\mathrm{P}<.01) \quad \mathrm{ADG}$ from 4 - 8 mos., $\mathrm{CxF}$ had better feed efficiency than FxF $(\mathrm{P}<.01)$ during the same period. Several studies indicated that $\mathrm{C} \times \mathrm{F}$ crosses gained weight faster, converted feed more efficiently and reached heavier SW compared to straightbred Friesian (Everitt et al., 1988; Southgate et al., 1982 and 1988, Mostageer et al., 1989 and More O'Ferrall and Keane, 1990).

Delay of slaughter from 4 to 8 or 12 months enhanced ADG, improved feed efficiency and doubled SW. Estimates of ADG were markedly higher from 8-12 mos. when compared to those of 4-8 months for both breed types. This was accompanied by greater feed consumption and better feed conversion. Present results are in agreement with Keane et al. (1990) and More O'Ferrall and Keane (1990).

Genotypic differences in carcass charcteristics were nonsignificant in all traits (Table 3). However, Charolais crosses tended to have higher DP (52.2 vs. $50.2 \%)$, yielding relatively heavier carcasses (126.8 vs. $119.5 \mathrm{~kg})$. Numerous studies indicated that the DP of Charolais, was higher than Friesian, (Berg and Butterfield, 1976; Kempster et al., 1982 and 1988; Mostageer et al., 1989 and More O'Ferrall and Keane, 1990). In the present study, the dairy breed, $\mathrm{F} \times \mathrm{F}$ deposited more non-carcass fat (1.34 vs. 1.17\%) than CxF. Khalil and Pirchner (1986) mentioned that impaired ADG and FCR of F xF as compared with those of dual purpose may be due to the greater accumulation of non-carcass relative to carcass fat. 
Table 2: Means and mean squares of slaughter weight, average daily gain, dry matter intake and feed conversion ratio of straightbred Friesian (FxF) and Friesian $\mathrm{x}$ Charolais (FxC)

\begin{tabular}{|c|c|c|c|c|c|c|}
\hline \multirow[b]{2}{*}{ Trait } & \multicolumn{3}{|c|}{ Mean } & & \multicolumn{2}{|c|}{ Mean squares } \\
\hline & $\mathrm{N}$ & $\mathrm{FxF}$ & $\mathrm{CxF}$ & SE & Genotype & Residual \\
\hline
\end{tabular}

$\mathrm{Sw}^{1}(\mathrm{~kg}):$

4 months

8 months

12 months

$\begin{array}{rll}18 & 106.4 & 104.0 \\ 12 & 196.7^{\mathrm{b}} & 221.0^{\mathrm{a}} \\ 6 & 376.0 & 392.7\end{array}$

392.7

$0.92^{\mathrm{a}}$

1.45

1.17

$6 \quad 1.13$

4-12 months

$\underline{D M I}^{3}(\mathrm{~kg}):$

4-8 months

8-12 months

4-12 months

\section{$\underline{\mathrm{FCR}}^{4}$}

4-8 months

8-12 months

4-12 months

$\begin{array}{rl}12 & 698 \\ 6 & 1066 \\ 6 & 1788\end{array}$

696

1063

1772

$6.37 \mathrm{~b}$

6.25

6.44
4.94

8.41

18.59

$27 \mathrm{NS}$

219

$1176^{*}$

417

425

1037

a,b Means, within rows, followed by different letters differ significantly $(\mathrm{P}<.05)$. ${ }^{1} \mathrm{SW}=$ slaughter weight.

${ }^{2} \mathrm{ADG}=$ average daily gain $=($ final body weight-initial body weight $) /$ days on feed. 3DMI $=$ dry matter intake $=$ The sum of roughage and concentrates on DM basis. $4 \mathrm{FCR}=$ feed conversion ratio $=\mathrm{DMI} /$ Weight gain.

NS, nonsignificant; $*=\mathrm{P}, .05$ and ${ }^{* *}=\mathrm{P}<.01$. 


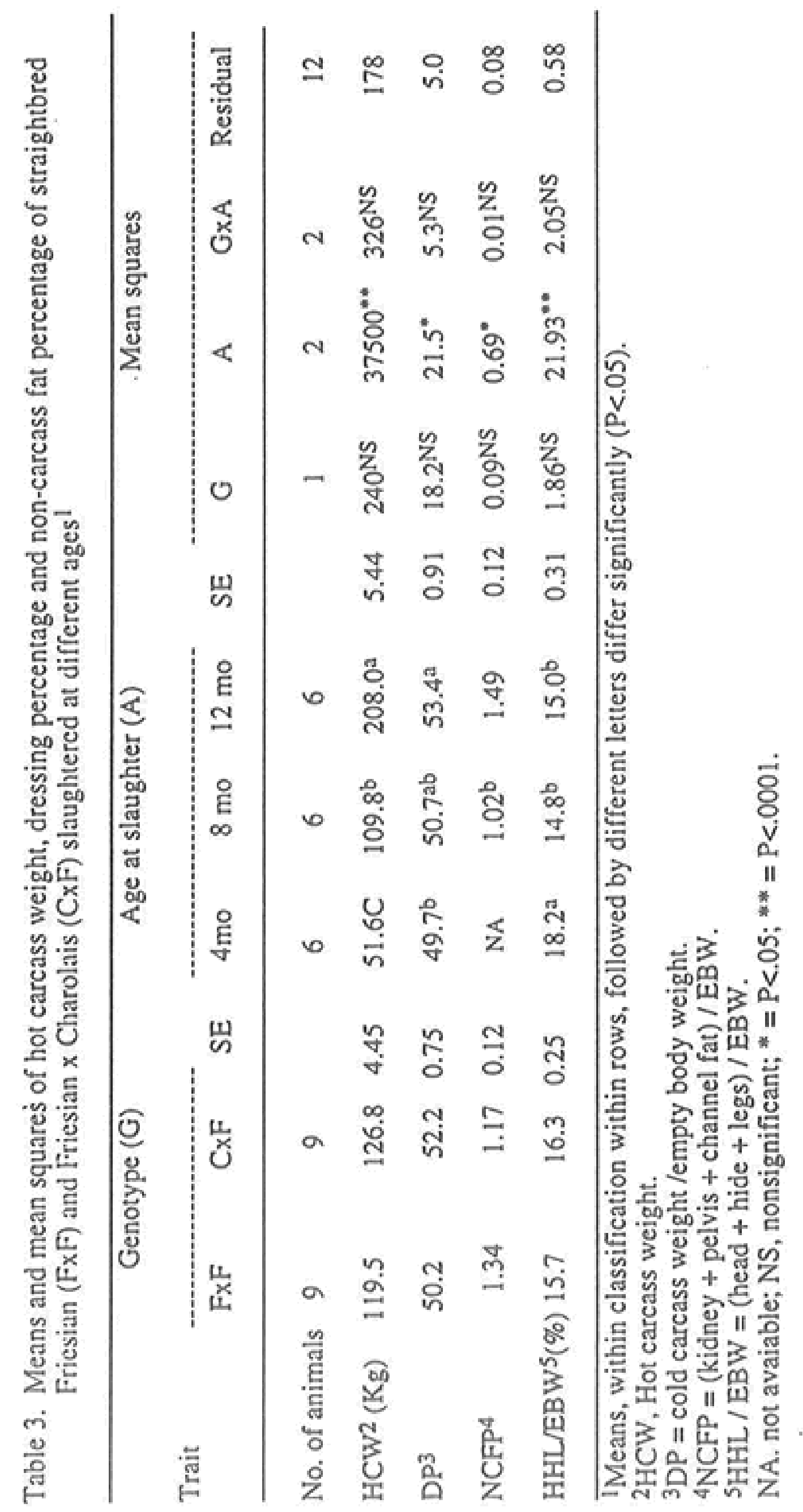


Delay of slaughtering from 4 to 8 or 12 months improved DP significantly $(49.7,50.7$ and $53.4 \%$, respectively). This was attributed to the increase in deposition of carcass tissues (HCW) and reduction of non-carcass percentage $(\mathrm{P}<.0001)$. Present data of an increasing DP with advance of animal age is in agreement with Berg and Butterfield (1976), and Mostageer et al. (1989). Hot carcass weight at 8 and 12 months was 2 and 4 times that at 4 months $(\mathrm{P}<.0001)$. This was accompanied by an increase of $0.4 \%$ non-carcass fat from 8 to 12 months.

Physical composition of the carcass represented by traits measured on the 9,10 and 11 rib cut is shown in Table 4. Breed type affected significantly $(\mathrm{P}<.05)(\mathrm{LDA})$. Charolais crosses had larger area compared to straightbred Friesian $\left(57.4 \mathrm{~cm}^{2}\right.$ vs. 46.5 $\mathrm{cm}^{2}$, respectively), indicating higher cutability. Eventhough, differences were not significant, Charolais crosses had more lean, less fat and bone in the $L$. dorsi muscles and less fat over the $9 \underline{\text { th }}$ rib. These findings are in agreement with previous studies indicating the superiority of Charolais and their crosses in carcass composition (Berg and Butterfield, 1976; Berg et al., 1978; Kempster et al., 1988 and More O'Ferrall and Keane, 1990).

Age at slaughter affected $(\mathrm{P}<.0001)$ all traits. Increasing slaughter age was accompanied by larger LDA. The reduction in bone exceeded $10 \%$ with advancement of age, means were $32.8,21.2$ and $22.4 \%$ for animals slaughtered at 4,8 and 12 months, respectively. Fatness of carcass, indicated by FT and \% ether extract increased progressively with advance of age.

Differences among groups in chemical composition were all nonsignificant (Table 5) except for the effect of age at slaughter on $\%$ ether extract in $L$. dorsi muscle $(\mathrm{P}<.01)$. However, crossing with Charolais tended to produce meat with more lean and less fat. These findings are confirmed by the data on physical composition of $L$. dorsi muscle and with reports reviewed by Berg and Butterfield (1976). 


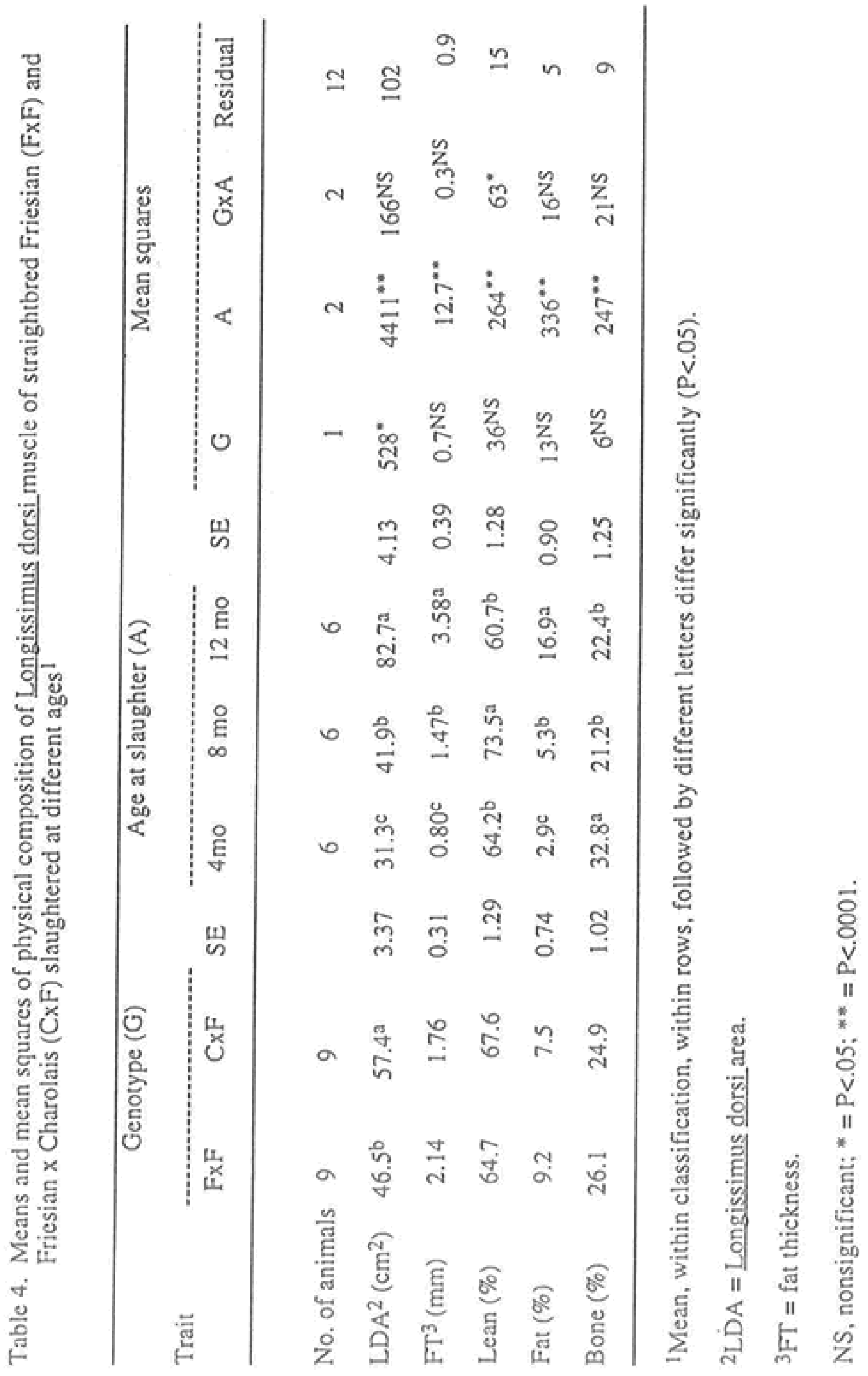




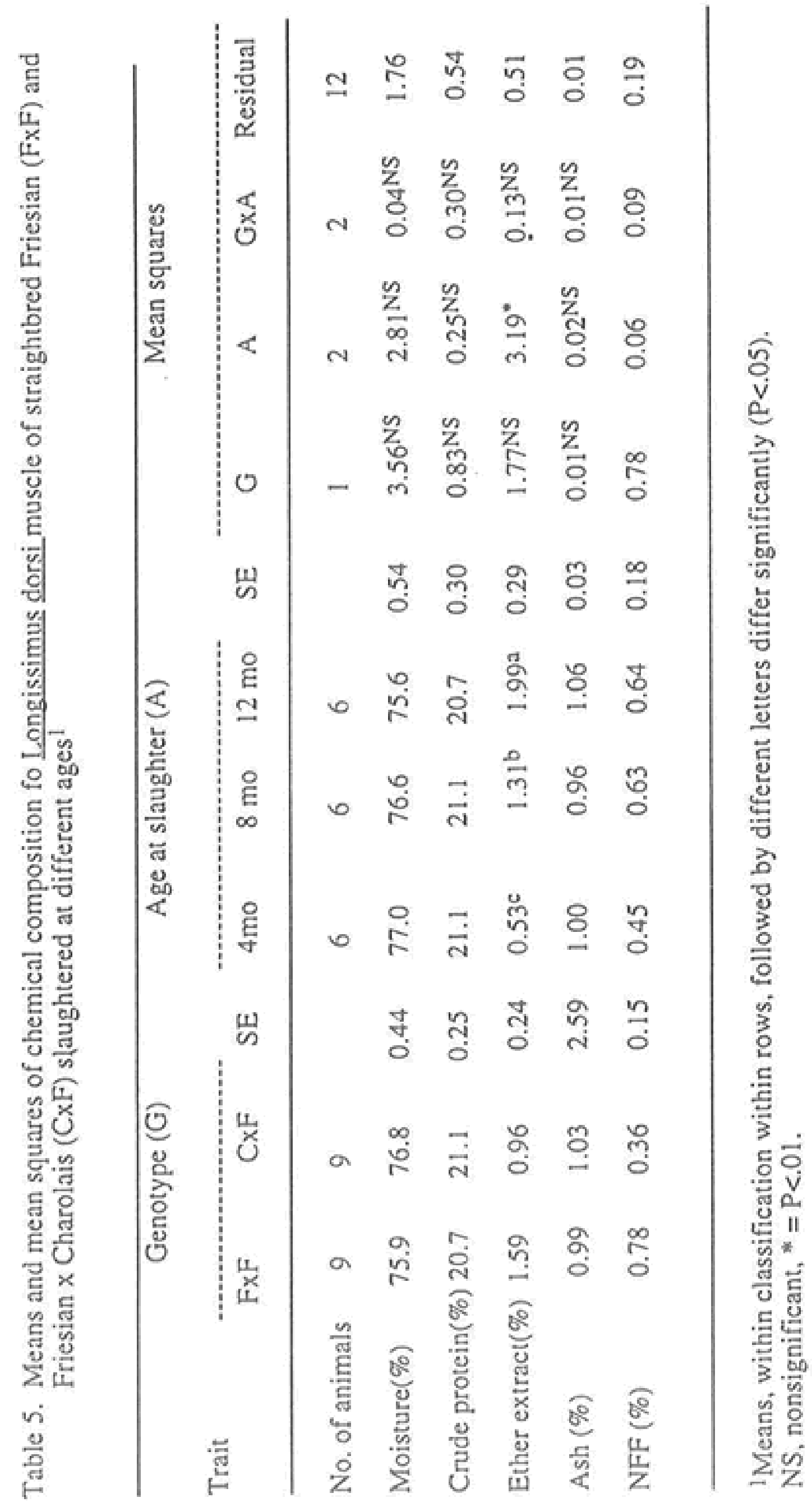


Using Charolais sires on Friesian herds would yield faster gain, better conversion, and enhance dressing percentage. In conclusion, results obtained from the present study recommend the use of Charolais coupled with delay of slaughter up to 12 months would be an effective means to improve efficiency of dairy beef production in the U.A.E. However, further research is required to determine the economic feasibility of using Charolais sires.

\section{ACKNOWLEDGMENT}

The assistance provided during the feeding period by Mr. M.M. Asker is highly appreciated.

\section{REFERENCES}

AOAC 1984. Official Methods of Analysis of the Association of Official Analytical Chemists. 14 th Ed. Arlington, VA.

Berg, R. T., B. B. Andersen, and T. Liboriussen, 1978. Growth of bovine tissues. 1. Genetic influences on growth pattern of muscle, fat and bone in young bulls. Anim. Prod. 26:245 258.

Berg, R. T. and R. M. Butterfield, 1976. "New Concepts of Cattle Growth" Sydney University Press, Sydney.

Everitt, G. C., K. E. Jury, D. C. Dalton and M. Langridge. 1980. Beef Production from the dairy herd. IV. Growth and carcass composition of straight-bred and beef-cross Friesian steers in several environments. N.Z. Journal of Agricultural Research 23:11-20.

Keane, M. G., G. J. More O'Ferrall, G. J. Connolly and P. Allen. 1990. Carcass composition of serially slaughtered Friesian, Hereford $\mathrm{x}$ Friesian and Charolais $\mathrm{x}$ Friesian steers finished on two dietary energy levels. Anim. Prod., 50: 231-243.

Kempster, A. J., G. L. Cook, and J.R. Southgate, 1982. A comparison of the progeny of British Friesian dams and different sire breeds in 16 and 24-month beef production systems. 2 Carcass characteristics, and rate and efficiency of meat gain. Anim. Prod. 34: 167-178. 
Kempster, A. J., G. L. Cook. and J. R. Southgate,1988. Evaluation of British Friesian, Canadian Holstein and beef breed $\mathrm{x}$ British Friesian steers slaughtered over a commercial range of fatness from 16-month and 24-month beef production systems. 2. Carcass characteristics, and rate and efficiency of lean gain. Anim. Prod. 46: 365-378.

Khalil, H. and F. Pirchner. 1986. Growth and carcass traits of bulls and veal calves of continental cattle breeds. 1. Growth and food conversion efficiency. Anim. Prod. 43: 225-233.

More O'Ferrall, G. J. and M. G. Keane. 1990. A comparison for live weight and carcass production of Charolais, Hereford and Friesian steer progeny from Friesian cows finished on two energy levels and serially slaughtered. Anim. Prod. 50:19-28.

Mostageer, A., F. Pirchner, M. A. Morsy, A. A. Nigm, N. S. Rashad and M. A. Ibrahim. 1989. The potential of cattle population. A slaughter test on Baladi and its crosses. Ruminant Production in the Dry Subtropics: Constraints and Potentials. EAAP Publication No. 38. Wageningen Netherlands, Pudoc p.107-113.

MSTAT 1985. Michigan State University. East Lansing, MI, U.S.A.

Southgate, J. R., G .L. Cook and A. J. Kempster. 1982. A comparison of the progeny of British Friesian dams and different sire breeds in 16- and 24-month beef production systems. 1. Live weight gain and efficiency of food utilization. Anim. Prod. 34: 155-166.

Southgate, J. R., G. L. Cook and A.J. Kempster. 1988. Evaluation of British Friesian, Canadian Holstein and beef breed $\mathrm{x}$ British Friesian steers slaughtered over a commercial range of fatness from 16-month and 24-month beef production systems. 1. Live weight gain and efficiency of food utilization. Anim. Prod. 46: 353-364. 
أداء ذكور أبقار الفريزيان وخليط الشاروليه المذبوحه عند ثلاث اعمار منتلفه علي نجم ، غالب الحضرمى ، عبد القادر خليف و عمر عبدالله

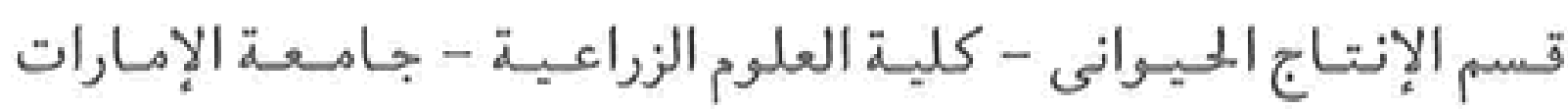

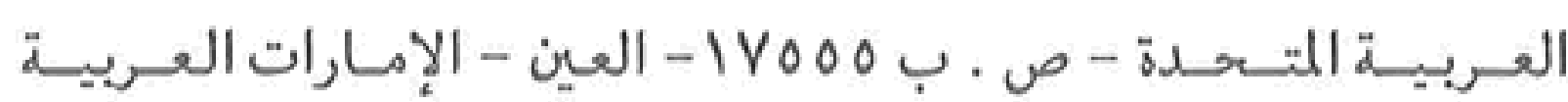

ملتصص :

تم استخدام ثمانية عشر عبلاً بعمر اربعة شهور في تجربة تسمين ، تسعه

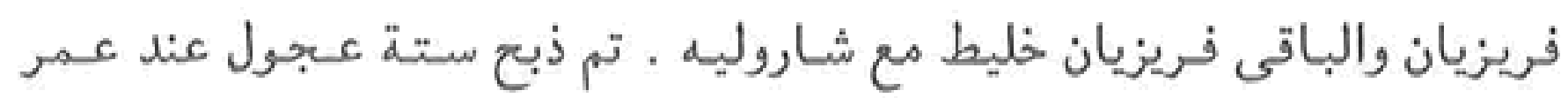
اربعة شهور والباقى تم تسمينه ثم ذبحه عند عمر ثمانيه أو اثنى عشر شهراً

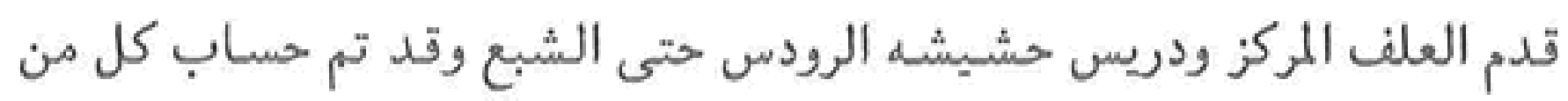

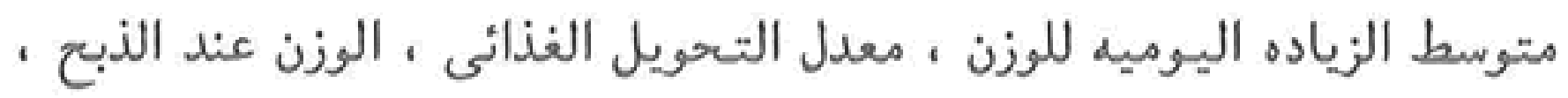

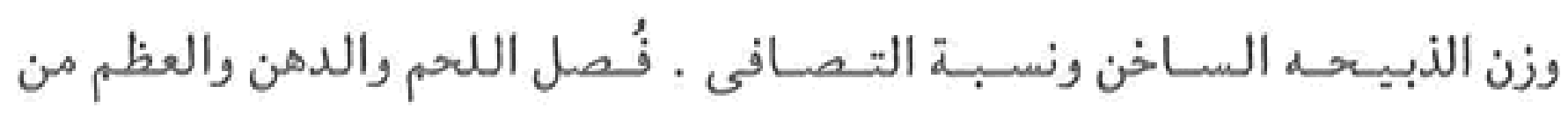
الضلع التاسع ، العـاشر والحمادي عشر كمـا اخذت مسـاحة العضلة العينيه وسـمك الدهن للضلع التـاسع ، اجحريت التـحليـلات الكيـــيـائيـه للتهم على العضلة العينيه . اعطي خليط الشاروليه اعلى متوسط للزيادة اليوميه في الوزن (P) ( P )

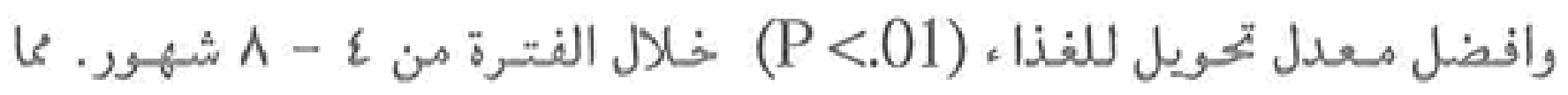

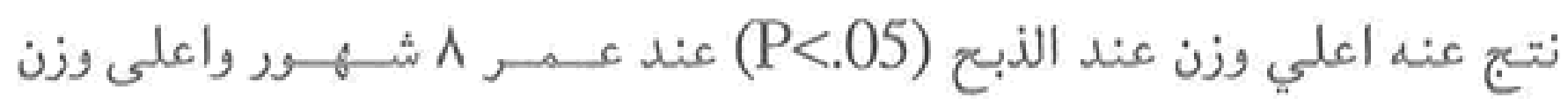
للذبيحه الساخنه واعلي نسبة للتصافى واعلي فى نسبة اللمم الأحمر و واقل 
في نسبة الدهن والعظم فى منطقه الضلوع ولكن الفروق كانت غير معنويه. ان زيادة مـسـاحـة العضلة العيـنيـة (P>05) في خليط الشـاروليـه دلالة علي زيادة عدد القطعيات .

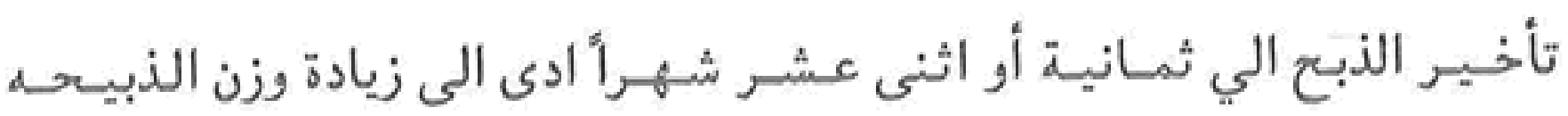

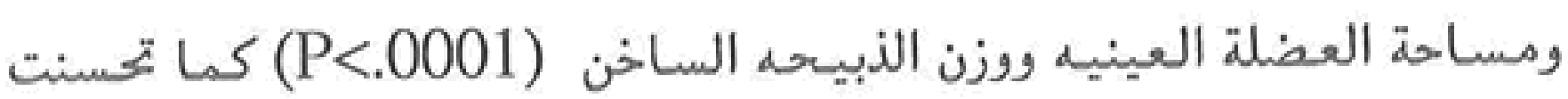

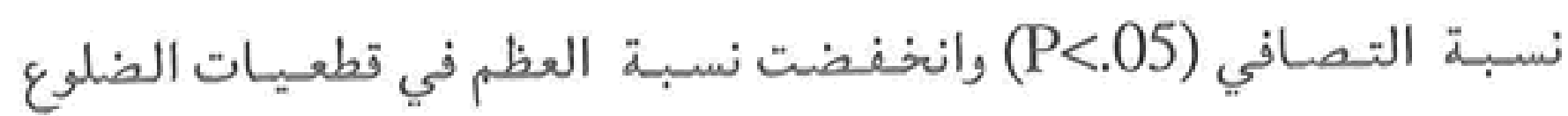

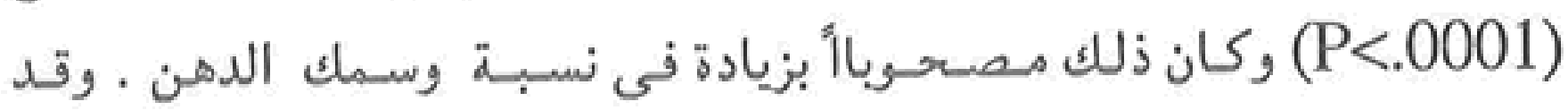

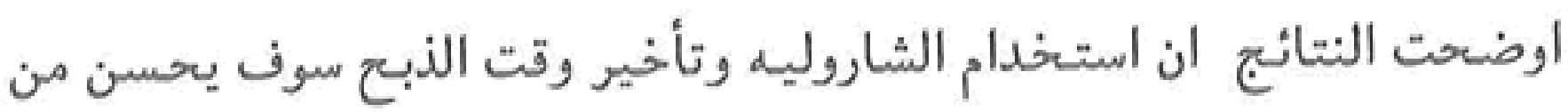
كفاءه انتاج اللحم من حيوانات الحليب فى دولة الإمارات العربية المتحدة . كلمات مفتاحيه : ذكور أبقار فريزيان ، شاروليه ، خليط ، الذبيحة . 